Prace Historyczno-Archiwalne t. XXXIII, Rzeszów 2021

ISSN: 1231-3335

\title{
Jakub Bodaszewski
}

ORCID 0000-0002-4100-7992

DOI:10.30657/pha.33.2021.02

(Archiwum Państwowe w Rzeszowie Oddział w Sanoku)

e-mail: bodaszewski88@vp.pl

\section{Gwardia Narodowa w Lesku w 1848 roku}

\section{Streszczenie}

Wybuch rewolucji w Wiedniu w marcu 1848 r. odnowił nadzieje Polaków w Galicji na uzyskanie niepodległości lub przynajmniej autonomii w ramach Cesarstwa Austriackiego. Podstawą dążeń patriotycznych było utworzenie oddziałów Gwardii Narodowej, początkowo w Krakowie i Lwowie, a później w mniejszych miejscowościach, m.in. w Lesku. Miasto to, liczące kilka tysięcy mieszkańców, stanowiło bazę rekrutacyjną dla nowo powstałych formacji. Składały się one w większości z rzemieślników i drobnomieszczaństwa. Dopiero pod koniec ich istnienia dopuszczono do nich chłopów. Gwardia Narodowa w Lesku posiadała liczne, wyszkolone zapewne w wojsku austriackim, grono oficerskie umożliwiające szkolenie wojskowe. Stanowiło to dopiero początek formowania jednostek polskich na terenach Galicji. Zarówno dowódcy, jak i patriotycznie nastawieni członkowie Gwardii Narodowej dawali nadzieję na stworzenie kadry, która w odpowiednim momencie będzie zdolna wywalczyć upragnioną przez Polaków niepodległość. Upadek nastrojów rewolucyjnych w Austrii spowodował stłumienie ruchów niepodległościowych na terenie Galicji. Wraz z powrotem reżimu wojskowego pod koniec 1848 r. zlikwidowano wszelkie zdobycze demokratyczne, powstałe w trakcie kilku zaledwie miesięcy, w tym również Gwardię Narodową. Formacja ta zlikwidowana została również w Lesku w styczniu 1849 r.

\section{Słowa kluczowe:}

Wiosna Ludów, 1846, Gwardia Narodowa, Lesko.

$\mathrm{R}$

ok 1848 był rokiem, w którym po raz kolejny Polacy próbowali odzyskać niepodległość. Kroki takie podjęto zarówno w zaborze pruskim, jak i w Galicji, gdzie początkowo chciano tylko autonomii w ramach cesarstwa austriackiego. Demokraci galicyjscy żądali równości wobec prawa dla obywateli wszystkich wyznań i stanów, demokratycznej ordynacji wyborczej, powszechnego nauczania, spolszczenia szkół i administracji, w tym sądów, likwidacji pańszczyzny i poddaństwa oraz 
nadania na własność ziemi ludności wiejskiej ${ }^{1}$. W późniejszym okresie miało dojść do odzyskania niepodległości. Najważniejsze miejsce w tych rachubach przypadało Gwardii Narodowej - jako zalążkowi przyszłego wojska polskiego.

Patent konstytucyjny, ogłoszony przez cesarza austriackiego po marcowym zwycięstwie rewolucji wiedeńskiej, umożliwił utworzenie Gwardii Narodowej. Była to jedyna, o określonej strukturze organizacyjnej, polska siła zbrojna w owym okresie. Stanowiła ona gwarancję utrzymania swobód obywatelskich wprowadzonych patentem cesarskim. Była również rękojmią bezpieczeństwa przed zaburzeniami wewnętrznymi oraz wystąpieniami chłopskimi. Traktowano ją jako zalążek armii polskiej na wypadek spodziewanej interwencji carskiej w Galicji lub wojny austriacko-rosyjskiej. Miała również bronić zdobyczy rewolucji przed spodziewaną kontrrewolucją ${ }^{2}$.

Na mocy praw konstytucyjnych Gwardia Narodowa była legalnie działającą formacją zbrojną na terenie Austrii. Oddziały jej w Galicji były tworzone samorzutnie, najpierw we Lwowie, a później w innych miastach. Istniejący stan rzeczy usankcjonował prawnie opublikowany przez Austriaków 8 kwietnia 1848 r. Statut dla organizowania Gwardii Narodowych $w$ Cesarstwie Austriackim. Określał on zasady organizowania kompanii i batalionów, pełnienia służby wewnętrznej i garnizonowej, podawał podstawy finansowe, zasady uzbrojenia, wyposażenia i umundurowania Gwardii Narodowej. Statut stanowił podstawę prawną istnienia tej formacji również na terenie Galicji ${ }^{3}$. Od tego momentu można było już legalnie rozbudowywać istniejące oddziały, zarówno w Krakowie, Lwowie, jak i w miastach okręgowych, miasteczkach i większych wsiach. Gwardia Narodowa miała być organizowana we wszystkich miejscowościach, które liczyły ponad 1000 mieszkańców. Mundur Gwardii mogli nosić mężczyźni między 19 a 60 rokiem życia, niebędący rzemieślnikami, służącymi, robotnikami dziennymi, robotnikami tygodniowymi. Wykluczono z niej także młodzież gimnazjalną i licealną, duchownych, żołnierzy, członków milicji krajowej, straży finansowej i straży bezpieczeństwa ${ }^{4}$. Administracja austriacka nie zgadzała się również na służbę czeladników, ograniczając równocześnie możliwość noszenia przez nich broni i mundurów. Po zniesieniu pańszczyzny, okólnikiem z 28 kwietnia 1848 r. zezwolono na wstępowanie do Gwardii Narodowej chłopom - właścicielom gospodarstw rolnych oraz ich synom.

Oddziały polskie w miastach obwodowych miały być organizowane przez komitety, składające się ze starostów, burmistrza lub reprezentanta magistratu, sześciu członków wydziału miejskiego oraz oficera wydelegowanego do tej czynności z miejscowego garnizonu. W pozostałych, mniejszych miasteczkach komitety organizacyjne Gwardii Narodowej składać miały się z delegata komisarza cyrkułu, burmistrza oraz trzech reprezentantów wydziału miejskiego i z oficera instruktora pododdzia$\mathrm{łu}^{5}$. Gubernator austriacki we Lwowie Franciszek Stadion zwlekał z ogłoszeniem pa-

1 Z. Fras, Demokraci galicyjscy w latach 1848-1875 [w:] Galicja i jej dziedzictwo, t. 1: Historia i polityka, Rzeszów 1994, s. 43-45.

2 M. Zgórniak, Dzieje Narodu i Państwa Polskiego. Za Waszq̨ i naszq wolność, Warszawa 1987, s. 32.

3 Archiwum Główne Akt Dawnych w Warszawie, Biblioteka Baworowskich, rkps. 277, Statut dla organizowania Gwardii Narodowych w Cesarstwie Austriackim, k. 141-150.

4 Ibidem, k. 141-142.

5 M. Stolarczyk, Galicyjska Gwardia Narodowa w 1848 r., cz. II: Od utworzenia Centralnej Rady Narodowej do wprowadzenia stanu wojennego we Lwowie [w:] Galicja i jej dziedzictwo, t. 15: Działalność wyzwoleńcza, Rzeszów 2001, s. 17. 
tentu, ale już 9 kwietnia 1848 r. odbyła się we Lwowie pierwsza defilada połączona z przeglądem oddziałów Gwardii Narodowej ${ }^{6}$. Następnego dnia gen. Józef Załuski poinformował, że obejmuje naczelne dowództwo nad oddziałami Gwardii Narodowej we Lwowie. Jego szefem sztabu został kpt. Edward Tadeusz Bieliński, adiutantem poeta Wincenty Pol, a instruktorem piechoty Franciszek Łoś7.

Już 13 kwietnia 1848 r. przystąpiono we Lwowie do tworzenia Rady Narodowej, przekształconej następnie w Centralną Radę Narodową. Organizowano równocześnie jej ogniwa terenowe w postaci Obwodowych Rad Narodowych ${ }^{8}$.

Centralna Rada Narodowa wyłoniła ze swojego składu osiem wydziałów. Wydział Gwardii Narodowej należy uznać za najważniejszy z nich. W jego skład wchodzili: Edward Duniewicz, Józef Łusakowski, Antym Nikorowicz, Antoni Golejowski, Wincenty Rogalski, Józef Siemańczewski i Hieronim Wyslobocki. To właśnie Wydział Gwardii zajmował się organizacją, uzbrojeniem, wyposażeniem i umundurowaniem oddziałów polskich. Obowiązki takie spoczywały również na dowództwie Gwardii Narodowej, dowództwach poszczególnych oddziałów i pododdziałów oraz na radach gospodarczych jednostek organizujących nowe oddziały ochotników ${ }^{9}$.

Obwodowej Radzie Narodowej w Sanoku podlegała Administracyjna Rada Gwardii Narodowej w Lesku ${ }^{10}$. Najprawdopodobniej już końcem kwietnia lub na początku maja 1848 r. zaczęto tam organizować Gwardię Narodową. Pierwszą wzmiankę o jej istnieniu zawiera „Protokół licytacji” z 31 maja 1848 r. Było to zamówienie na uszycie kitli u krawca dla oddziału ochotników z Leska ${ }^{11}$. Organizowane na terenie Galicji oddziały Gwardii Narodowej przyjmowały struktury kompanii wojskowych. Najpierw kompletowano listy ochotników i mężczyzn zobowiązanych do służby. Nie przejmowano się jednak takimi kwestiami, jak przydatność do służby wojskowej. Zaplecze rekrutacyjne było dość skromne. Obejmowało początkowo jedynie właścicieli posiadłości miejskich, kupców, rzemieślników, inteligencję i szlachtę. Uniemożliwiało to utworzenie licznych oddziałów. Fakt rozszerzenia poboru na właścicieli gospodarstw wiejskich i ich synów po zniesieniu pańszczyzny niewiele w tym zakresie zmieniał. Na powołanie do Gwardii Narodowej chłopów nie mogli się zdecydować polscy demokraci. Sprzeciwiał się też temu gubernator austriacki Franciszek Stadion.

Duża część patriotycznego społeczeństwa polskiego postrzegała Gwardię Narodową jako przyszłą armię powstańczą. W związku z tym na gwardzistach ciążyły wielorakie obowiązki. Musieli się oni przygotować do trudu i życia wojskowego, poznać broń i nabyć umiejętności posługiwania się nią oraz nauczyć się musztry podstawowej i bojowej. Dodatkowo mieli być agitatorami sprawy narodowej ${ }^{12}$.

6 Ibidem, s. 11.

7 Rozkaz dzienny do Gwardii Narodowej, „Dziennik Narodowy”, nr 15 z 10 IV 1848 r.

8 M. Stolarczyk, Działalność lwowskiej Centralnej Rady Narodowej, Rzeszów 1994, s. 87-93.

9 K. Adamek, Polskie gwardie narodowe w Galicji w $1848 r$., „Studia i Materiały do Historii Wojskowości", t. XIX, cz. I, Białystok 1973, s. 279.

10 J. Budziak, Dzieje Leska 1772-1918, Lesko 1995, s. 96. Pod Obwodową Radę Narodową w Sanoku podlegała również Gwardia Narodowa w Brzozowie, zob. J. Bodaszewski, Gwardia Narodowa w Brzozowie w 1848 r., „Prace Historyczno-Archiwalne”, t. XXIX, Rzeszów 2017, s. 173-187.

11 Archiwum Państwowe w Przemyślu, Archiwum Zamku Leskiego Krasickich [dalej: APPrz, Archiwum Zamku Leskiego], sygn. 383, s. 128.

12 M. Stolarczyk, Galicyjska Gwardia Narodowa w 1848 r. [w:] Galicja w 1848 roku: demogra- 
Gwardziści zobowiązani byli sami się uzbroić, umundurować i wyposażyć. $\mathrm{Na}$ tego typu wydatki mogli sobie pozwolić tylko najbogatsi ochotnicy. Większość musiała liczyć na finansową pomoc gmin, cyrkułów i wojska oraz ofiarność społeczną. Wobec szczupłych możliwości finansowych magistratów, niechęci administracji państwowej i wojska, liczono przede wszystkim na patriotyzm i składki publiczne społeczeństwa polskiego. Przez cały krótki okres swojego istnienia galicyjska Gwardia Narodowa cierpiała wiele niedostatków.

Na uzbrojenie, umundurowanie i wyposażenie Gwardii Narodowej potrzebne były znaczne sumy pieniędzy. Koszt wyekwipowania jednego gwardzisty pieszego wynosił 33 talary, a konnego aż 55 talarów. Całkowity koszt uzbrojenia, umundurowania i wyposażenia 20000 gwardzistów to 660000 talarów. Kwotą taką nie dysponowała Centralna Rada Narodowa we Lwowie ani też dowództwo Gwardii ${ }^{13}$. Składki publiczne starczały zaledwie na zaspokojenie najpotrzebniejszych wydatków.

Najwięcej na wyposażenie Gwardii w Lesku łożył hrabia Edmund Krasicki, pełniący funkcję jej dowódcy w stopniu kapitana. Mógł on z jednej strony mieć przeświadczenie o swej wyjątkowej roli przywódczej w zniewolonym społeczeństwie polskim z racji przynależenia do arystokracji, a z drugiej strony, być może powodował nim strach przed powtórzeniem niedawnej przecież rabacji chłopskiej ${ }^{14}$. Były to prawdopodobne przyczyny objęcia przez niego dowództwa nad Gwardią Narodową w Lesku oraz łożenia gotówki na wyposażenie nowo powstałej jednostki. Początkowo, w lipcu $1848 \mathrm{r}$. Krasicki wpłacił gotówką 90 zł, w sierpniu, jako jedyny, 10 zł, we wrześniu - 464 zł, a w październiku 55 zł. Z tych środków 460 zł przeznaczono na zakup broni, a 4 zł na uszycie furażerek. Znaczną kwotę podarował także Karol Skibiński - „Obywatel z Uherec”, bo aż 100 zł. Do obowiązku pomocy materialnej poczuwali się też oficerowie: porucznik Robert Barański, w „gotowiźnie” przeliczonej na pieniądze, przekazał $50 \mathrm{zł}$, porucznik Franciszek Wolski - 1 zł 40 groszy, a niejaki Nowosielski - 4 zł z przeznaczeniem na uszycie furażerek. Przed lipcem 1848 r. pieniądze na rzecz Gwardii Narodowej ofiarowali także lescy Żydzi: Moszko Dym Niebieszczański - 2 zł, Nuchim Ginsberg, Hersch Dym Niebieszczański, Mendel Wołoski, Noe Weiberg, Joles Feinwel, Hersch Alpern, Hersch Woloski, Mojzes Weinfeld, Josel Manaster, Pinkus Reischer, Herszko Niebieszczański (handlarz końmi - najprawdopodobniej nie była to osoba tożsama ze wspomnianym wyżej Herschem Dymem Niebieszczańskim) - wszyscy po 1 zł, lekarz Ignacy Kahany (występujący także jako Kahane) - 40 groszy, Abraham Iser, Izak Dym, Abraham Axtmaier, Wolf Spira - każdy po 30 groszy oraz Kelman Spira i Lipa Dym po 20 groszy. Łącznie Izraelici lescy zebrali 15 zł. Pieniądze wpłacali tylko na początku działalności Gwardii Narodowej; od lipca 1848 r. do stycznia 1849 r. nie wspomagali już oni finansowo polskiej działalności patriotycznej. Łącznie od 1 lipca do 29 października 1848 r. uzbierano 831 zł w gotówce ${ }^{15}$. Działalność oddziału wspierali również sami gwardziści. Hrabia Edmund Krasicki, pełniący funkcję dowódcy w randze kapitana, ufundował 13 czapek, 12 kitli (były to najprawdopodobniej bluzy mundurowe), 4

fia, działalność polityczna i społeczna, gospodarka i kultura, red. A. Bonusiak, M. Stolarczyk, Rzeszów 1999, s. 79.

13 Ibidem, s. 86.

14 K. Karolczak, Arystokraci galicyjscy wobec wypadków 1848 r. [w:] Rok 1848. Wiosna Ludów w Galicji. Zbiór studiów, red. W. Wic, Kraków 1999, s. 51, 55.

15 APPrz, Archiwum Zamku Leskiego, sygn. 18, s. 9-10. 
pary spodni płóciennych. Podarował też skórę na 46 ładownic z rzemieniami. Porucznik Barański zapłacił za uszycie 14 czapek, porucznik Adam Borejko opłacił uszycie 8 kitli, a podoficer Ginsberg - 10 kitli. Niejaki Stetkiewicz podarował frak, z którego wykonano 18 czapek, a Franciszek Wolski zapłacił za płótno przeznaczone na 10 kitli. Ze wspólnych składkowych pieniędzy kompanijnych dodatkowo zakupiono: 16 czapek, 20 kitli, 19 karabinów i 1 bęben ${ }^{16}$. Przyjmowano wszelką pomoc - np. porucznik Borejko ofiarował na zimę ławkę na odwach ${ }^{17}$. Lekarz Ignacy Kahane obiecał wszelką pomoc medyczną ${ }^{18}$. Dodatkowe dochody uzyskano także dzięki zorganizowanemu 24 października 1848 r. koncertowi amatorów instrumentalno-wokalnych, połączonemu z deklamacją wierszy przez Zygmunta Kaczkowskiego ${ }^{19}$.

Przede wszystkim należało zabezpieczyć stały dopływ uzbrojenia i amunicji. Było to konieczne nie tylko do ćwiczeń, ale także do ewentualnego podjęcia działań zbrojnych. Austriacy wprawdzie dostarczali niekiedy uzbrojenie, ale było ono już mocno przestarzałe. W owym czasie, w miejsce przekazywanych Gwardii Narodowej karabinów skałkowych, wojsko austriackie wprowadzało już nowocześniejsze karabiny kapiszonowe ${ }^{20}$. Część strzelb, jak już wspomniano, podarował lub kupił hrabia Krasicki, część zakupiono z funduszy kompanii leskiej. Według „Rozchodu w pieniądzach”, 23 lipca 1848 r. nabyto 2 karabiny od Męczyńskiego (w dokumencie nie podano jego imienia), 13 od Jana Jankiewicza oraz kolejne dwa bez zapisania źródła ich zakupu. Kolejna transakcja nastąpiła 6 sierpnia 1848 r. - kupiono wtedy po jednym karabinie od niejakiej Osękowskiej i „z Kostrzynia od Maiko”. Najprawdopodobniej oba były uszkodzone, jako że za ich naprawę 17 września Jan Jankiewicz wziął 5 zł. Wykonywał on także bagnety. Za pośrednictwem posła do parlamentu wiedeńskiego, Bogusława Longchamps de Berier ${ }^{21}$, uzyskano 50 sztuk karabinów z Przemyśla ${ }^{22}$. Brakowało też amunicji. W październiku 1848 r. porucznik Robert Barański z sierżantem niewymienionym z nazwiska wykonali 240 ładunków do karabinów. Z powyższego można wnosić, że w dyspozycji Gwardii Narodowej były przestarzałe już wtedy karabiny skałkowe. Na podstawie „Rozchodu Munduru i Armatury” można obliczyć stan uzbrojenia Gwardii Narodowej w Lesku w październiku 1848 r. Gwardziści posiadali 59 karabinów, w większości z bagnetami i ładownicami. Żaden nie miał szabli czy tasaka wojskowego. Część gwardzistów jednak nie dostała karabinów i pozostawała bez uzbrojenia ${ }^{23}$.

Chociaż dokładano wszelkich starań, wciąż brakowało broni, jednak pomimo braków w uzbrojeniu, umundurowaniu i wyposażeniu, ochotnicy byli gotowi w stosownej chwili walczyć o niepodległość Polski.

Większość zebranych pieniędzy i naturaliów przeznaczono, oprócz zakupu broni i amunicji, na umundurowanie i wyposażenie: szycie czapek, furażerek, kitli, ale także kupno i naprawę bębna, zakup sznura do bębna oraz naukę dobosza.

16 Ibidem, s. 14.

17 Ibidem, s. 21.

18 Ibidem, s. 18.

19 APPrz, Archiwum Zamku Leskiego, sygn. 383, s. 105.

20 M. Stolarczyk, Galicyjska Gwardia Narodowa w 1848 r. [w:] Galicja w 1848 roku: demografia..., s. 85.

21 B. Łopuszański, Longchamps (Longchamps de Berier) Bogusław (1808-1888) [w:] Polski Słownik Biograficzny, t. XVII, Wrocław 1972, s. 540-541.

22 APPrz, Archiwum Zamku Leskiego, sygn. 18, s. 11-12.

23 Ibidem, s. 15-17. 
Prace przy wyposażeniu w znacznej mierze wykonywali miejscowi rzemieślnicy. Kitle szył Kazimierz Czucz, ładownice wykonywali Stanisław Grabowski i niewymieniony z imienia Szymanowski, zaś Jankowski (najprawdopodobniej chodzi tu o ślusarza Jana Jankiewicza, a nie Jankowskiego) naprawiał karabiny i sporządzał bagnety ${ }^{24}$. Jak z tego widać, nie korzystano z usług obcych dostawców ani wykonawców. Wszystko szyto lub reperowano na miejscu, wykorzystując miejscowych rzemieślników oraz samych gwardzistów. Ponadto dobosz kompanijny Marceli Nadziak otrzymał 5 złotych za służbę od 1 kwietnia do 15 października 1848 r. $^{25}$

Już po kilkumiesięcznym istnieniu Gwardii Narodowej w Galicji uznano, że konieczne jest nadanie jej jednolitego wojskowego wyglądu. Szczególnie wyraźne było to w oddziałach pieszych. Formę i wygląd munduru dla wszystkich gwardzistów przyjęto bardzo szybko, bo już 14 kwietnia 1848 r. na posiedzeniu dowództwa Gwardii we Lwowie. Na głowie gwardzista nosił kaszkiet lub czapkę czworograniastą amarantową, z czarną, lakierowaną z przodu skórą i utwardzanym daszkiem. Mundury składały się z luźnych kurtek mundurowych i spodni z sukna. Kurtki miały kolor granatowy z amarantowymi wypustkami na rękawach i na kołnierzu. Zapinano je na 9 białych, gładkich guzików z przodu i sześć guzików z tyłu. Spodnie miały kolor szary („sieraczkowe koloru stalowego”), z amarantową wypustką i strzemiączkami do odpinania. Całość uzupełniała czarna chusta na szyi. Umundurowanie letnie wyglądało nieco inaczej - okrągła furażerka z wypustkami oraz szara kurtka i spodnie bez wypustek. Na kołnierzu kurtki miały być naszyte 2 patki koloru amarantowego. Szyto je z płótna, a nie z sukna. Dla rozróżnienia wprowadzono na prawej ręce szawron amarantowy, pojedynczy dla podoficerów, a podwójny dla sierżanta. Mundur dopełniały czarne pasy z lakierowanej skóry, z których jeden był pasem ładownicy, a drugi służył do noszenia krótkiego tasaka piechoty $^{26}$.

Z zachowanego „Rozchodu Munduru i Armatury” Gwardii Narodowej leskiej, najprawdopodobniej z października 1848 r., można poznać stan umundurowania tejże formacji. W spisie wykazano 85 gwardzistów, jednak bez podania ich stopni wojskowych (oprócz Ksawerego Barańskiego - sierżanta). Żaden z nich nie posiadał czaka, a większość zaopatrzona była w czapki/furażerki sukienne i kitle (najprawdopodobniej bluzy). Spodnie uszyto tylko dla 4 ochotników. Sierżant Barański sam zakupił dla siebie mundur: czapkę, kitel i spodnie. Natomiast hr. Edmund Krasicki ufundował mundur dla Jana Filara. Nikt nie został zaopatrzony w buty ${ }^{27}$. Jak więc widać, większość gwardzistów została umundurowana przynajmniej częściowo.

Z konieczności musiano nadać Gwardii Narodowej takie formy organizacyjne, jakie obowiązywały w ówczesnych armiach. Prasa polska w Galicji sugerowała, że kompanie Gwardii Narodowej powinny się składać ze 116 gwardzistów, z tego 102

24 Ibidem, s. 11-13.

25 Ibidem, s. 19.

26 Lwowska Naukowa Biblioteka im. W. Stefanyka NAN Ukrainy we Lwowie, Oddział Rękopisów, zespół (fond) 5, Rękopisy Biblioteki Zakładu Narodowego im. Ossolińskich, 5458/II, Rozkazy dzienne Lwowskiej Gwardii Narodowej 1848 r. (od 4 VIII - 31 X), k. 2; S. Gepner, Żołnierz polski. Ubiór, uzbrojenie i oporządzenie. Okres 1832-1939, Warszawa 2014, s. 85-86; E. Quirini, Ubiór, oporzq̨dzenie i uzbrojenie lwowskiej Gwardii Narodowej w r. 1848, „Studia do Dziejów Dawnego Uzbrojenia i Ubioru Wojskowego", cz. III, Kraków 1967, s. 49-69.

27 APPrz, Archiwum Zamku Leskiego, sygn. 18, s. 15-17. 
szeregowych, 11 podoficerów, w tym 2 sierżantów, oraz z 3 oficerów. Kompaniami Gwardii Narodowej dowodzili przeważnie oficerowie w stopniu kapitana ${ }^{28}$.

Zachowane dokumenty z jesieni 1848 r. - jak: „Lista patroli nocnej odbytej przez Gwardię Liską”, „Lista Inspekcji i Warty Wtorkowej”, „Lista inspekcji i patroli nocnej” oraz „Rozchód Munduru i Armatury” - pozwalają określić liczebność Gwardii Narodowej w Lesku. Liczba ochotników wahała się od 85 do 111, zbliżała się więc do pełnego stanu kompanii. Nowi gwardziści dołączali do jednostki nawet pod koniec października (Ludwik Wohner z Chrewtu) czy listopada 1848 r. (Józef Przygoda, majster kowalski aż z Bulowic k. Wadowic) ${ }^{29}$.

Wśród nazwisk figurujących w tych wykazach 6 należało do Żydów (Józef Szpinetor, Ditrich Rozental, Mortko Walkenberg, Mendel Aron Woloski, Ginsberg, Ignacy Kahane/Kahany), a jedno do Rusina (Filaret Miejski - opuścił jednostkę). Resztę rekrutów oraz całe dowództwo stanowili Polacy. W kompanii leskiej służyli wszyscy chętni, bez względu na pochodzenie społeczne, narodowość czy wyznanie. Wspólna służba w Gwardii Narodowej podkreślała równość obywateli wobec prawa, umożliwiała też awans wojskowy, z czym szedł w parze awans społeczny. Był to czynnik przyśpieszający powstanie nowoczesnego narodu polskiego, składającego się ze wszystkich klas społecznych, wielu narodowości i wyznań.

Ochotnicy wstępowali do oddziałów Gwardii nierzadko po kilku z rodziny, jak np.: Wojciech i Marceli Nadziak, Jan Nycz stary i Jan Nycz junior, Kazimierz Czucz i Franciszek Czucz. Reprezentowali różne zawody, m.in.: poczmistrz, aptekarz, sędzia, lekarz, mandatariusz, technik, woźny, krawiec, kowal, szewc, rzeźnik, murarz, ślusarz, kołodziej, bednarz, stolarz, piekarz, kotlarz, siodlarz, malarz, kapelusznik, cukiernik i organista $^{30}$. Dzięki takiemu składowi kompania mogła być całkowicie samowystarczalna podczas prowadzenia działań wojennych. Z list zwerbowanych do Gwardii wykluczono z różnych przyczyn zaledwie 3 osoby, które wystąpiły bez podania powodu i oddały otrzymaną broń (Filaret Miejski, Antoni Józefczyk i Antoni Krupski).

Szkoleniem wojskowym zajmowali się oficerowie i podoficerowie. Wywodzili się oni zapewne z wojska austriackiego. W Lesku, tak jak w innych oddziałach Gwardii Narodowej, stanowiska podoficerskie i oficerskie były obsadzane w drodze wyborów dokonywanych przez ogół gwardzistów. Dowództwo Gwardii Narodowej we Lwowie, w piśmie z 2 czerwca 1848 r. do hr. Edmunda Krasickiego, wyraziło aprobatę dla dokonanego przez żołnierzy wyboru dowódców do kapitana włącznie ${ }^{31}$. $\mathrm{Na}$ „Liście inspekcji i patroli nocnej” z 1848 r. wymieniono oficerów dowodzących Gwardią Narodową w Lesku. Dowódcą był hr. Edmund Krasicki w randze kapitana jako komendant, porucznikami Adam Borejko i Robert Barański, podporucznikami Franciszek Wolski, Bogusław Longchamps i Ksawery Topolnicki, sierżantami Ksawery Barański i Filaret Miejski (po jego odejściu funkcję przejął Wenanty Cieszanowski), podoficerami niższej rangi: Wojciech Jankiewicz, Andrzej Janiszewski, Wincenty Różycki, Jan Filar, Józef Szpinator, Stanisław Grabowski, Antoni Hobcus, Jan Hobcus, Jan Jasiński, Michał Górka, Piotr Filar, Józef Grabowski ${ }^{32}$. Wszyscy oficerowie tworzyli

\footnotetext{
28 „Dziennik Narodowy”, nr 2 z 25 III 1848 r., s. 7.

29 APPrz, Archiwum Zamku Leskiego, sygn. 18, s. 19, 21.

30 Ibidem, s. 7.

31 Ibidem, sygn. 383, s. 40.

32 Ibidem, sygn. 18, s. 6.
} 
Radę Gwardii; zachowały się protokoły sesji tegoż organu od 17 września 1848 r. do 14 stycznia 1849 r. Zajmowano się sprawami zaopatrzenia jednostki, gospodarczymi, przydzielaniem wart, przyjęciem nowych członków ${ }^{33}$.

Ochotnicy codziennie pełnili warty i patrole nocne pod dowództwem podoficera, przeprowadzali również parady i ćwiczyli musztrę ${ }^{34}$. Ostatnia warta nocna złożona z 2 gwardzistów odbyła się 27 stycznia $1849 \mathrm{r}^{35}$ Dodatkowo obarczono ich obowiązkiem gaszenia pożarów i dbania o porządek i bezpieczeństwo w mieście ${ }^{36}$. Gwardziści, wśród których większość stanowili rzemieślnicy, kupcy i urzędnicy, mogli uczestniczyć w ćwiczeniach wojskowych w bardzo ograniczonym zakresie - tym bardziej, że dzień pracy w owym czasie trwał 14 godzin (od 5.00 do 19.00). Nie było też urlopów czy innych usprawiedliwionych zwolnień z pracy ${ }^{37}$.

Leska Gwardia Narodowa pomagała także przy zwalczaniu epidemii cholery pod koniec października 1848 r. Utworzono w tej sprawie trzyosobową komisję koordynującą działania przeciwepidemiczne. Porucznik Barański ofiarował pieniądze na lekarstwa dla biednych dotkniętych chorobą ${ }^{38}$.

Gwardia Narodowa nie posiadała regulaminu dyscyplinarnego. Mimo to przełożonym i starszym przysługiwało w ograniczonym stopniu prawo do karania i nagradzania podwładnych ${ }^{39}$. Jedyny przypadek niesubordynacji, a nawet dywersji zdarzył się na początku października 1848 r., kiedy to Antoni Zwierzyński namawiał gwardzistów, aby nie chodzili na ćwiczenia z musztry ${ }^{40}$. Z zachowanych materiałów archiwalnych nie wynika jednak, czy został za ten czyn ukarany.

Dość późno, bo dopiero 6 października 1848 r., w Sanoku odbyło się poświęcenie sztandaru Gwardii Narodowej. Na wydarzenie to zaproszono również przedstawicieli kompanii z Leska. Była to podniosła uroczystość, połączona z poświęceniem chorągwi, salwami karabinowymi, pieśniami religijnymi i procesją ${ }^{41}$. Trzeba tu wspomnieć, że znaczna część rzymskokatolickiego duchowieństwa galicyjskiego, zgodnie z zaleceniami Centralnej Rady Narodowej, organizowała uroczystości patriotyczne, wygłaszała kazania, szerzyła ideę odrodzenia państwa polskiego ${ }^{42}$. Podobnie rzecz się miała w Lesku i Sanoku. W dokumentach nie zachowały się natomiast informacje o składaniu przysięgi wojskowej przez Gwardię Narodową, tak z Sanoka, jak i z Leska.

W 1848 r. właściciele zamku leskiego, Edmund hrabia z Siecina Krasicki i jego żona Maria Aniela z Brzostowskich, ufundowali figurę Matki Boskiej. Ich herby (Ro-

33 Ibidem, s. 18-21.

34 J. Budziak, Dzieje Leska 1772-1918, Lesko 1995, s. 97.

35 APPrz, Archiwum Zamku Leskiego, sygn. 383, s. 35.

36 Ibidem, s. 38.

37 Adres czeladzi wszystkich rzemiosł do Rady Narodowej, „Rada Narodowa”, nr 6 z 27 IV 1848 r., s. 22-23.

38 APPrz, Archiwum Zamku Leskiego, sygn. 18, s. 20.

39 M. Stolarczyk, Lwowska i galicyjska Gwardia Narodowa w 1848 r., cz. I: Od rewolucji wiedeńskiej do utworzenia Centralnej Rady Narodowej, „Zeszyty Naukowe Wyższej Szkoły Pedagogicznej w Rzeszowie", Seria Społeczno-Pedagogiczna i Historyczna, Historia 5, z. 19/1995, Rzeszów 1995, s. 95-96.

40 APPrz, Archiwum Zamku Leskiego, sygn. 18, s. 18.

41 Ibidem, sygn. 383, s. 137.

42 M. Stolarczyk, Udział duchowieństwa rzymskokatolickiego w galicyjskiej Wiośnie Ludów. Próba charakterystyki [w:] Rok 1848. Wiosna Ludów w Galicji..., s. 66. 
gala i Strzemię) znajdują się na frontowej ścianie postumentu, na którym umieszczono statuę (stojącą obecnie na placu Konstytucji 3 Maja w Lesku). Gest ten był wyrazem patriotycznej postawy mieszkańców miasta w owym okresie. Według miejscowej tradycji, figura Matki Bożej była podziękowaniem za uratowanie Leska przed rzezią podczas rabacji chłopskiej w $1846 \mathrm{r}^{43}$

2 listopada 1848 r. wojska austriackie zbombardowały Lwów. Gwardia Narodowa skapitulowała i została rozwiązana. W stolicy Galicji wprowadzono stan oblężenia, rozszerzając go następnie na całą prowincję. Zlikwidowano Gwardię Narodową oraz wszystkie polskie organizacje i wydawnictwa, a działaczy patriotycznych internowano lub wcielono do wojska austriackiego ${ }^{44}$. Część z nich zbiegło i uczestniczyło w powstaniu węgierskim ${ }^{45}$. Po wprowadzeniu stanu oblężenia w Galicji pod koniec 1848 r. Polacy masowo przekradali się na Węgry i wstępowali do wojsk powstańczych. Z tego powodu podjęto starania o utworzenie tam większej jednostki polskiej. W Galicji zaczęły się tworzyć samorzutnie komitety niosące pomoc uciekinierom, zbierające fundusze na zakup broni oraz werbujące ochotników do powstania węgierskiego. Komitet lwowski dążył do przerzutu jak największej liczby ludzi w celu utworzenia na Węgrzech legionów polskich - zalążka armii polskiej, która miałaby wkroczyć do Galicji i ewentualnie, w razie wybuchu ogólnopolskiego powstania, uderzyć na Rosję ${ }^{46}$.

Jednym z wielu ochotników udających się na Węgry był Marceli Nadziak, dobosz kompanii Gwardii Narodowej w Lesku. Urodził się w 1832 r. w Tuchowie jako syn Wojciecha Nadziaka i Weroniki z Michaleckich. W 1848 r. ukończył pierwszy rok gimnazjum w Tarnowie. Późną jesienią zdołał przedostać się z Leska na Węgry, gdzie już na początku grudnia tegoż roku służył w szwadronie 2. Pułku Ułanów i uczestniczył w bitwie pod Barcą. Wkrótce został przeniesiony do oddziału strzelców majora Rembowskiego ${ }^{47}$. Po upadku powstania udał się do Turcji i tam został podoficerem Legionu Polskiego na Węgrzech ${ }^{48}$. Około 1850 r. powrócił na teren Galicji, gdzie wcielono go do armii austriackiej. Służbę zakończył w stopniu sierżanta ${ }^{49}$. Zmarł w $1905 \mathrm{r}$. w Ustianowej.

Kres istnieniu Gwardii Narodowej w Galicji przyniosło wprowadzenie 10 stycznia 1849 r. stanu wojennego na obszarze całej prowincji. Trwał on aż do 1854 r. Zlikwidowano w ten sposób ostatecznie demokratyczną działalność polską ${ }^{50}$. W Lesku ostatni wpis o Gwardii Narodowej pojawia się w protokole odbytych wart nocnych

43 A. Chmura, Cudowna figura, „Skarby Podkarpackie” 2008, nr 3(10), s. 2.

44 M. Śliwa, Rok 1846 w Galicji i późniejsza Rewolucja 1848 [w:] Rok 1848 Wiosna Ludów w Galicji..., s. 19.

45 M. Zgórniak, Dzieje Narodu i Państwa..., s. 37.

46 Ibidem, s. 62.

47 I. Kovacs, Honwedzi, emisariusze, legioniści. Słownik biograficzny polskich uczestników Wiosny Ludów na Węgrzech 1848-1849, Kraków 2016, s. 488.

48 J. Wysocki, Pamiętnik Jenerała Wysockiego, dowódcy Legionu Polskiego na Węgrzech z czasu kampanii węgierskiej w roku 1848 i 1849, Poznań 1985, s. 446.

49 I. Kovacs, Honwedzi, emisariusze..., s. 488.

50 M. Stolarczyk, Reorganizacja i upadek lwowskiej Centralnej Rady Narodowej w 1848 r., „Zeszyty Naukowe Wyższej Szkoły Pedagogicznej w Rzeszowie", Seria Społeczno-Pedagogiczna i Historyczna, Historia 2, z. 3, Rzeszów 1991, s. 33-53. 
z 27 stycznia $1849 \mathrm{r}^{51} \mathrm{~W}$ tym samym okresie zlikwidowano także Radę Administracyjną i Radę Gospodarczą. Zgromadzoną broń przejęło wojsko austriackie ${ }^{52}$.

Wydarzenie Wiosny Ludów w Galicji nie były samodzielnym polskim czynem niepodległościowym. Wybuchły one na wieść o rewolucji w Wiedniu. Swoje zdobycze, takie jak opisana tu Gwardia Narodowa, zachowywały tak długo, jak długo zwyciężała rewolucja wiedeńska ${ }^{53}$. Po jej upadku wprowadzono reżim wojskowy i rządy reakcji, likwidując wszystkie osiągnięcia demokratyczne, w tym Gwardię Narodową jako zalążek przyszłego wojska polskiego.

Aneks 1. Wykaz członków Gwardii Narodowej w Lesku w październiku 1848 r.

\begin{tabular}{|c|c|c|c|c|}
\hline L.p. & Nazwisko i imię & Stopień & Zajęcie & Uwagi \\
\hline 1. & Krasicki Edmund & kapitan & [hrabia] & \\
\hline 2. & Borejko Adam & porucznik & poczmistrz & \\
\hline 3. & Barański Robert & porucznik & aptekarz & \\
\hline 4. & Wolski Franciszek & podporucznik & sędzia & \\
\hline 5. & Longchamps Bogusław & podporucznik & lekarz & \\
\hline 6. & Topolnicki Ksawery & podporucznik & mandatariusz & \\
\hline 7. & Barański Ksawery & sierżant & - & \\
\hline 8. & Miejski Filaret & sierżant & - & $\begin{array}{l}\text { zrezyg- } \\
\text { nował }\end{array}$ \\
\hline 9. & Jankiewicz Wojciech & podoficer & - & \\
\hline 10. & Janiszewski Andrzej & podoficer & technik & \\
\hline 11. & Różycki Wincenty & podoficer & krawiec & \\
\hline 12. & Filar Jan & podoficer & $\begin{array}{l}\text { gospodarz/właściciel } \\
\text { gruntu? }\end{array}$ & \\
\hline 13. & Spinator Józef & podoficer & woźny & \\
\hline 14. & Grabowski Stanisław & podoficer & siodlarz & \\
\hline 15. & Hobcus Antoni & podoficer & kowal & \\
\hline 16. & Hobcus Jan & podoficer & kowal & \\
\hline 17. & Jasiński Jan & podoficer & krawiec & \\
\hline 18. & Górka Michał & podoficer & krawiec & \\
\hline 19. & Filar Piotr & podoficer & $\begin{array}{l}\text { gospodarz/właściciel } \\
\text { gruntu? }\end{array}$ & \\
\hline 20. & Grabowski Józef & podoficer & pisarz [gminny] & \\
\hline 21. & Słotwiński Jakub & towarzysz/gwardzista & krawiec & \\
\hline 22. & Czerwiński Jan & towarzysz/gwardzista & rzeźnik & \\
\hline
\end{tabular}

51 APPrz, Archiwum Zamku Leskiego, sygn. 383, s. 137.

52 Ibidem, sygn. 479, s. 1-3.

53 M. Śliwa, Rok 1846 w Galicji i późniejsza Rewolucja 1848 [w:] Rok 1848 Wiosna Ludów w Galicji..., s. 19. 


\begin{tabular}{|c|c|c|c|}
\hline 23. & Raiński Michał & towarzysz/gwardzista & szewc \\
\hline 24. & Różycki Tomasz & towarzysz/gwardzista & $\begin{array}{l}\text { gospodarz/właściciel } \\
\text { gruntu }\end{array}$ \\
\hline 25. & Słotwiński Feliks & towarzysz/gwardzista & szewc \\
\hline 26. & Czucz Kazimierz & towarzysz/gwardzista & krawiec \\
\hline 27. & Czucz Franciszek & towarzysz/gwardzista & krawiec \\
\hline 28. & Hobcus Michał & towarzysz/gwardzista & $\begin{array}{l}\text { gospodarz/właściciel } \\
\text { gruntu }\end{array}$ \\
\hline 29. & Rachlewicz Antoni & towarzysz/gwardzista & szewc \\
\hline 30. & Kaliński Walenty & towarzysz/gwardzista & kowal \\
\hline 31. & Nycz Jan stary & towarzysz/gwardzista & kowal \\
\hline 32. & Słotwiński Michał & towarzysz/gwardzista & szewc \\
\hline 33. & Różycki Antoni & towarzysz/gwardzista & kowal \\
\hline 34. & Filar Józef & towarzysz/gwardzista & $\begin{array}{l}\text { gospodarz/właściciel } \\
\text { gruntu }\end{array}$ \\
\hline 35. & Nycz Jan junior & towarzysz/gwardzista & kowal \\
\hline 36. & Cholewicki Antoni & towarzysz/gwardzista & szewc \\
\hline 37. & Darowski Michał & towarzysz/gwardzista & krawiec \\
\hline 38. & Kaliński Szymon & towarzysz/gwardzista & $\begin{array}{l}\text { gospodarz/właściciel } \\
\text { gruntu }\end{array}$ \\
\hline 39. & Zwierzyński Antoni & towarzysz/gwardzista & kowal \\
\hline 40. & Różycki Jan & towarzysz/gwardzista & krawiec \\
\hline 41. & Kabaj Jan & towarzysz/gwardzista & $\begin{array}{l}\text { gospodarz/właściciel } \\
\text { gruntu }\end{array}$ \\
\hline 42. & Staszewski Andrzej & towarzysz/gwardzista & szewc \\
\hline 43. & Domaradzki Franciszek & towarzysz/gwardzista & szewc \\
\hline 44. & Zakrzewski Józef & towarzysz/gwardzista & szewc \\
\hline 45. & Zwierzyński Michał & towarzysz/gwardzista & krawiec \\
\hline 46. & Krzywowiąza Antoni & towarzysz/gwardzista & siodlarz \\
\hline 47. & Belec Andrzej & towarzysz/gwardzista & murarz \\
\hline 48. & Belec Antoni & towarzysz/gwardzista & murarz \\
\hline 49. & Kozłowski Tomasz & towarzysz/gwardzista & murarz \\
\hline 50. & Kozłowski Wincenty & towarzysz/gwardzista & krawiec \\
\hline 51. & Muszyński Antoni & towarzysz/gwardzista & ślusarz \\
\hline 52. & Polański Antoni & towarzysz/gwardzista & kowal \\
\hline 53. & Rachlewicz Michał & towarzysz/gwardzista & szewc \\
\hline 54. & Zwierzyński Mikołaj & towarzysz/gwardzista & $\begin{array}{l}\text { gospodarz/właściciel } \\
\text { gruntu }\end{array}$ \\
\hline
\end{tabular}


Jakub Bodaszewski

\begin{tabular}{|c|c|c|c|}
\hline 55. & Słotwiński Andrzej & towarzysz/gwardzista & rzeźnik \\
\hline 56. & Zakrzewski Kasper & towarzysz/gwardzista & stolarz \\
\hline 57. & Muszyński Franciszek & towarzysz/gwardzista & kołodziej \\
\hline 58. & Grzybowski Tomasz & towarzysz/gwardzista & kowal \\
\hline 59. & Baran Jakub & towarzysz/gwardzista & rzeźnik \\
\hline 60. & Baran Jan & towarzysz/gwardzista & murarz \\
\hline 61. & Kozłowski Antoni & towarzysz/gwardzista & szewc \\
\hline 62. & Horniatkiewicz Józef & towarzysz/gwardzista & szewc \\
\hline 63. & Kilarski Ignacy & towarzysz/gwardzista & organista \\
\hline 64. & Widacki Adam & towarzysz/gwardzista & piekarz \\
\hline 65. & $\begin{array}{l}\text { Słotwiński Jakub młod- } \\
\text { szy }\end{array}$ & towarzysz/gwardzista & bednarz \\
\hline 66. & Grzybowski Ludwik & towarzysz/gwardzista & szewc \\
\hline 67. & Kityński Matiasz & towarzysz/gwardzista & rzeźnik \\
\hline 68. & Ogonowski Piotr & towarzysz/gwardzista & stolarz \\
\hline 69. & Zieliński Jan & towarzysz/gwardzista & kapelusznik \\
\hline 70. & Hegenberger Jerzy & towarzysz/gwardzista & cukiernik \\
\hline 71. & Różycki Andrzej & towarzysz/gwardzista & kowal \\
\hline 72. & Filar Tomasz & towarzysz/gwardzista & $\begin{array}{l}\text { gospodarz/właściciel } \\
\text { gruntu? }\end{array}$ \\
\hline 73. & Sokołowski Jan & towarzysz/gwardzista & szewc \\
\hline 74. & Jasiński Wojciech & towarzysz/gwardzista & stolarz \\
\hline 75. & Słotwiński Antoni & towarzysz/gwardzista & szewc \\
\hline 76. & Giermak Antoni & towarzysz/gwardzista & $\begin{array}{l}\text { gospodarz/właściciel } \\
\text { gruntu? }\end{array}$ \\
\hline 77. & Starakiewicz Józef & towarzysz/gwardzista & szewc \\
\hline 78. & Starakiewicz Dominik & towarzysz/gwardzista & szewc \\
\hline 79. & Chrapkiewicz Józef & towarzysz/gwardzista & $\begin{array}{l}\text { gospodarz/właściciel } \\
\text { gruntu? }\end{array}$ \\
\hline 80. & Makowski Piotr & towarzysz/gwardzista & szewc \\
\hline 81. & Męciński Ferdynand & towarzysz/gwardzista & ślusarz \\
\hline 82. & Ramzynski Piotr & towarzysz/gwardzista & rzeźnik \\
\hline 83. & Brynkiewicz Marcin & towarzysz/gwardzista & rzeźnik \\
\hline 84. & Wolkenberg Mordko & towarzysz/gwardzista & Żyd \\
\hline 85. & Domaradzki Błażej & towarzysz/gwardzista & rzeźnik \\
\hline 86. & Krupski Antoni & towarzysz/gwardzista & kominiarz? \\
\hline 87. & Szypajło Wojciech & towarzysz/gwardzista & malarz \\
\hline 88. & Fuks Franciszek & towarzysz/gwardzista & szewc \\
\hline
\end{tabular}




\begin{tabular}{|c|c|c|c|}
\hline 89. & Ott Karol & towarzysz/gwardzista & aptekarz \\
\hline 90. & Krzyżanowski Marcin & towarzysz/gwardzista & nauczyciel \\
\hline 91. & Kmieć Michał & towarzysz/gwardzista & $\begin{array}{l}\text { gospodarz/właściciel } \\
\text { gruntu? }\end{array}$ \\
\hline 92. & Janiczek Ignacy & towarzysz/gwardzista & malarz \\
\hline 93. & Jankiewicz Jan & towarzysz/gwardzista & ślusarz \\
\hline 94. & Szrot Szczepan & towarzysz/gwardzista & - \\
\hline 95. & Klement Aleksander & towarzysz/gwardzista & - \\
\hline 96. & Nadziak Wojciech & towarzysz/gwardzista & - \\
\hline 97. & Misiewicz Antoni & towarzysz/gwardzista & krawiec \\
\hline 98. & Berezik Piotr & towarzysz/gwardzista & szewc \\
\hline 99. & Przygoda Józef & towarzysz/gwardzista & kowal \\
\hline 100. & Nadziak Marceli & dobosz & - \\
\hline 101. & Kahany/Kahane Ignacy & lekarz kompanii & lekarz \\
\hline 102. & Cieszanowski Wenanty & sierżant & „kotlarze z okolicy” \\
\hline 103. & Bal Jan & towarzysz/gwardzista & kotlarz \\
\hline 104. & Skulicz Sylwester & towarzysz/gwardzista & kotlarz \\
\hline 105. & Oszuchowski Andrzej & towarzysz/gwardzista & kotlarz \\
\hline 106. & Oszuchowski Sylwester & towarzysz/gwardzista & kotlarz \\
\hline 107. & Wohner Ludwik & towarzysz/gwardzista & kotlarz \\
\hline 108. & Bielecki Józef & towarzysz/gwardzista & kotlarz \\
\hline 109. & Popiel Antoni & towarzysz/gwardzista & kotlarz \\
\hline 110. & Truskolaski Franciszek & towarzysz/gwardzista & kotlarz \\
\hline 111. & Borowski Leon & towarzysz/gwardzista & kotlarz \\
\hline
\end{tabular}

Źródło: Archiwum Państwowe w Przemyślu, Archiwum Zamku Leskiego Krasickich, sygn. 18, s. 6-8.

\section{Bibliografia}

\section{Dokumenty i archiwa:}

\section{Archiwum Główne Akt Dawnych w Warszawie}

Biblioteka Baworowskich, rkps 277, Statut dla organizowania Gwardii Narodowych $w$ Cesarstwie Austriackim.

\section{Archiwum Państwowe w Przemyślu}

Archiwum Zamku Leskiego Krasickich, sygn. 18.

Archiwum Zamku Leskiego Krasickich, sygn. 383.

Archiwum Zamku Leskiego Krasickich, sygn. 479. 
Lwowska Naukowa Biblioteka im. W. Stefanyka NAN Ukrainy we Lwowie

Oddział Rękopisów, zespół (fond) 5, Rękopisy Biblioteki Zakładu Narodowego im. Ossolińskich, 5458/II, Rozkazy dzienne Lwowskiej Gwardii Narodowej 1848 r. (od 4 VIII - 31 X).

\section{Prasa:}

„Dziennik Narodowy”, nr 2 z 25 III 1848 r.

„Dziennik Narodowy”, nr 15 z 10 IV 1848 r.

„Rada Narodowa”, nr 6 z 27 IV 1848 r.

„Skarby Podkarpackie” 2008, nr 3(10).

\section{Opracowania:}

K. Adamek, Polskie gwardie narodowe w Galicji w 1848 r., „Studia i Materiały do Historii Wojskowości", t. XIX, cz. I, Białystok 1973.

J. Bodaszewski, Gwardia Narodowa w Brzozowie w 1848 r., „Prace Historyczno-Archiwalne" 2017, t. XXIX, Rzeszów 2017.

J. Budziak, Dzieje Leska 1772-1918, Lesko 1995.

Z. Fras, Demokraci galicyjscy w latach 1848-1875 [w:] Galicja i jej dziedzictwo, t. 1: Historia i polityka, Rzeszów 1994.

B. Łopuszański, Longchamps (Longchamps de Berier) Bogusław (1808-1888) [w:] Polski Słownik Biograficzny, t. XVII, Wrocław 1972.

S. Gepner, Żołnierz polski. Ubiór, uzbrojenie i oporządzenie. Okres 1832-1939, Warszawa 2014.

K. Karolczak, Arystokraci galicyjscy wobec wypadków 1848 r. [w:] Rok 1848. Wiosna Ludów w Galicji. Zbiór studiów, red. W. Wic, Kraków 1999.

I. Kovacs, Honwedzi, emisariusze, legioniści. Słownik biograficzny polskich uczestników Wiosny Ludów na Węgrzech 1848-1849, Kraków 2016.

E. Quirini, Ubiór, oporządzenie i uzbrojenie lwowskiej Gwardii Narodowej w r. 1848, „Studia do Dziejów Dawnego Uzbrojenia i Ubioru Wojskowego”, cz. III, Kraków 1967.

M. Stolarczyk, Działalność lwowskiej Centralnej Rady Narodowej, Rzeszów 1994.

M. Stolarczyk, Galicyjska Gwardia Narodowa w 1848 r. [w:] Galicja w 1848 roku: demografia, działalność polityczna i społeczna, gospodarka i kultura, red. A. Bonusiak, M. Stolarczyk, Rzeszów 1999.

M. Stolarczyk, Galicyjska Gwardia Narodowa w 1848 r., cz. II: Od utworzenia Centralnej Rady Narodowej do wprowadzenia stanu wojennego we Lwowie [w:] Galicja i jej dziedzictwo, t. 15: Działalność wyzwoleńcza, Rzeszów 2001.

M. Stolarczyk, Lwowska i galicyjska Gwardia Narodowa w 1848 r., cz. I: Od rewolucji wiedeńskiej do utworzenia Centralnej Rady Narodowej, „Zeszyty Naukowe Wyższej Szkoły Pedagogicznej w Rzeszowie", Seria Społeczno-Pedagogiczna i Historyczna, Historia 5, z. 19, Rzeszów 1995.

M. Stolarczyk, Reorganizacja i upadek lwowskiej Centralnej Rady Narodowej w 1848 r., „Zeszyty Naukowe Wyższej Szkoły Pedagogicznej w Rzeszowie”, Seria Społeczno-Pedagogiczna i Historyczna, Historia 2, z. 3, Rzeszów 1991. 
M. Stolarczyk, Udział duchowieństwa rzymskokatolickiego w galicyjskiej Wiośnie Ludów. Próba charakterystyki [w:] Rok 1848. Wiosna Ludów w Galicji. Zbiór studiów, red. W. Wic, Kraków 1999.

M. Śliwa, Rok 1846 w Galicji i późniejsza Rewolucja 1848 [w:] Rok 1848. Wiosna Ludów w Galicji. Zbiór studiów, red. W. Wic, Kraków 1999.

J. Wysocki, Pamiętnik Jenerała Wysockiego, dowódcy Legionu Polskiego na Węgrzech z czasu kampanii węgierskiej w roku 1848 i 1849, Poznań 1985.

M. Zgórniak, Dzieje Narodu i Państwa Polskiego. Za Waszq̨ i naszq wolność, Warszawa 1987.

\begin{abstract}
National Guard in Lesko in 1848

The outbreak of the March 1848 revolution in Vienna renewed the hope of Poles living in Galicia, who wished to regain independence or at least gain autonomy within the Austrian Empire. The beginning of patriotic endeavors was founding the National Guard in Cracow and Lviv, and later in smaller towns, such as Lesko. The city, with a population of several thousand, became the recruiting ground for the newly-formed formations. These formations were comprised mostly of artisans and the petite bourgeoisie. Only at the end of its existence were peasants allowed to join the Guard. The National Guard in Lesko had numerous officers, likely trained in the Austrian army, who provided military training. This was only the beginning of the formation of Polish units in Galicia. Both the commanders and the patriotic members of the National Guard brought hope of establishing a cadre that, in the right moment, would be able to fight for the longed for Polish independence. The Polish independence movements were suppressed as soon as the revolutionary sentiment in Austria abated. With the introduction of the military regime at the end of 1848, every single democratic concession made during these several short months was revoked, including the formation of the National Guard. The formation in Lesko was abolished in 1849.
\end{abstract}

\title{
Keywords:
}

Lesko, National Guard, 1846, Springtime of Nations. 